\title{
NEW DIRECTIONS FOR ECONOMIC DEVELOPMENT STRATEGIES IN THE SOUTH
}

\author{
W. Joe Lanham*
}

\section{Introduction}

\begin{abstract}
"We are, indeed, in a new world, and that shouldn't come as a shock to us. We have worked to create it for more than 30 years. We have helped build other nations by providing aid, sharing scientific knowledge, tranferrring technologies, educating their young people, and contributing to the growth of global commerce ... We are dealing now with the other side of the coin. In helping create this new world, we've also created strong, competitive nations... We must now contend with a number of problems, including the danger of losing more than 30 years of international economic dominance. Our basic domestic industries are losing ground to foreign competitors, and even our technological prowess is being questioned. What then lies ahead of us ... a an era of continued success or an era of decline?

"The new technologies hold great promises, but their realization involves many difficulties--not just scientific and technological ones, but difficulties that are economic, social, and political. In short, technological change fosters economic growth, but it involves growing pains. I believe we can live with them and prevail, because we're stronger than we think. Indeed, no nation has ever faced the future from a position of greater strength."1
\end{abstract}

In the foregoing article, Dr. Ross correctly and succinctly points to the challenges of dealing with a changing world and he then reinforces our faith in our ability to turn problems into opportunities as we identify and act together in new directions for appropriate economic development strategies. Certainly I, and many others, share this optimism and we agree that we can effectively utilize our human resources, research and education capabilities, and a responsive economic and political system to build on the considerable concensus and cooperation that we already have to meet these new needs.

All around us-today and as we look toward the future-we are cognizant of a new social, political, and economic era. Roles of the federal Government have changed in recent years. Federal dollars for state and local projects are shifting and decreasing. Many people have moved to rural areas. Entire basic industries are being restructured. Whole categories of occupations are being eliminated or severely curtailed. These and similar type changes are reason enough for us to carefully consider our economic development agenda for the remainder of the 1980 s and into the ' $90 \mathrm{s.}^{2}$

New directions for economic development strategies in the South must include putting together a stronger knowledge base which analyzes the basic economic trends that are occurring in the region and their relationship to the total economy. We need to look at the present and the long term vitality of our basic industries, particularly those with aging physical plants or that adversely affect our resource base or environment. We also need objective and rigorous analyses of the total potential for jobs and job locations in the broad area that we refer to as high technology. Additionally, we need to look thoroughly

*Program Leader, Economic Development, Natural Resources and Rural Development, Extension Service, U.S. Department of Agriculture, Washington, D.C. 
at the occurring manpower changes with implications drawn for retraining potential, as well as the need for shifts in the kinds of basic vocational/technical training being provided in the region. And, certainly, we need substantial understanding of the relationships between tax policy and the financing of our basic public infrastructure in the years ahead.

In my view, we have been gaining much needed momentum over the last 2-3 years in economic development interest and activities. We are now at, or approaching, the crest of a wave of public and private sector sentiment to really move ahead in a significant manner. We have several analytical tools that are being used effectively here and there in the region, and we need to make wider use of these economic development tools as rapidly as possible. The several papers that follow provide discussion about economic development strategies background, policy alternatives, technology options and implications, and the applications to communities, state government, state legislation, and the role of the university.

All the resources of the region-human, economic, institutional, and natural-must be identified and effectively mobilized to meet the challenge of change. In the South-as in all of America-we must recognize that "with change comes opportunity."

\section{FOOTNOTES}

1From article, "America-With Change Comes Opportunity," by Ian M. Ross, President of Bell Laboratories, in Economic Development Review, Volume 2, Number 1, American Economic Development Council, Schiller Park, IL, Winter, 1984.

${ }^{2}$ For some of the thoughts expressed in this section, I am indebted to Dr. Ronald C. Powers, Director, North Central Regional Center for Rural Development, who summarized major portions of the Community Economic Development Strategies Conference, Omaha, NE, March 1-3, 1983. 